\title{
Atmospheric and Turbocharged Experimental Investigation of Heavy Vehicle Compressor Air Inlet Line
}

\author{
Gökselhan Kula $^{1 *}$, Murat Ciniviz ${ }^{2}$ \\ 0000-0001-5328-6311, 0000-0003-3512-6730
}

${ }^{1}$ R\&D Department/Yıldız Pul Otomotiv Motor Parçaları Sanayi A.Ş., Turkey

${ }^{2}$ Mechanical Engineering, Selcuk University, Konya,, Turkey

\begin{abstract}
Reciprocating compressors, which come from the past to the present and whose development is parallel to internal combustion engine technologies, find themselves a large share in this field in line with the innovative studies on it. The stored compressed air demanded in the heavy vehicle segment, where almost all diesel engines are used, is serviced for two main tasks such as brake and suspension system. Therefore, the engine to be used during the compressor selection; efficiency, performance and service maintenance period are very important while meeting the demands and what applications are used such as long-distance vehicle, construction site vehicle, transport vehicle, garbage truck, coach.

In this paper, experimental studies were carried out on a Scania brand diesel vehicle by feeding the air brake compressor from the engine turbocharger intercooler with an improved interconnection and conventional atmospheric feeding. Temperature and pressure values obtained via sensors from the data collection system, performance information obtained from the vehicle CAN module and exhaust emission measurement results measured by opacimeter for both cases are presented.
\end{abstract}

Keywords: Compressor volumetric efficiency, Data acquisition, Piston compressors, Turbocharger

\author{
* Corresponding author \\ Gökselhan Kula \\ gokselhankula@gmail.com
}

Adress: Ankara Yolu Üzeri Konsan Sanayi Bölgesi 10727 Sk.No: 32 Pk: 42050 Konya / Turkey

Tel: +90 3323462540

Researh Article

Manuscript

Received 22.05.2020

Revised 28.08.2020

Accepted $\quad 04.09 .2020$

Doi: 10.30939/ijastech..740142

\section{Introduction}

Nowadays, the air pressurized to the tanks on the vehicle by piston air brake compressors is used for the main duties such as brake system, clutch mechanism, transmission, suspension bellows. In addition, the issues which is explained above also acceptable such as doors of buses, tire inflation and cleaning (especially tractors) for the other purposes. Therefore, today there are some systems in most heavy duty vehicle tanks that let the vehicle not move until enough air is obtained unless there is enough air [1].

The normal operating (duty) cycle is mentioned in the troubleshooting guides of the main industrial compressor manufacturers. Duty cycle; it is the ratio of the total time spent by the compressor in the load state when generating compressed air to the total engine run time. Reciprocating air compressors are designed with a single or twin cylinder to produce compressed air up to $25 \%$ of the engine cycle time [2]. High operating cycles cause conditions that affect the performance of the air brake charging system which may require additional maintenance. Unlike routine service period, this additional maintenance may cause extra costs and service time.

In this study, experiments were carried out by developing a conventional (atmospheric feeding) air intake line of a piston compressor and a turbocharged air supply line as in today's internal combustion engines. During the driving of heavy vehicles, experimental studies were carried out at the three cycles (750 rpm, $1250 \mathrm{rpm}, 1750 \mathrm{rpm}$ ), usually preferred. Engine indicated torque and fuel consumption were measured by means of a related software via CAN, tank filling times, turbocharged air pressure and temperature values were measured by sensors related to the data collection system and the compressor volumetric efficiency was calculated. In each test cycle, the measured and calculated values of two different compressor air supply lines are plotted and the results are interpreted. With this study, it is aimed to shorten the compressor tank filling time, increase the inlet air volu- 
metric efficiency, decrease the fuel consumption of the compressor at load and thereby serve the required compressed air shorter than the normal duty cycle and increase the compressor working life.

Some studies in the literature are as follows:

A. Shinde and Jadhav worked on pressure surge, one of the biggest problems with the compressor system. In order to reduce energy consumption, achieve safe operation and monitor the condition of multiple compressors, they have turned off the unnecessarily working compressor (without affecting the desired pressure amount) by using a touch screen PLC and consequently provided a high degree of protection against the high temperatures [3].

Naser et al. developed a zero-dimensional model to accurately describe the processes occurring in a multi-cylinder, turbocharged and intercooled Cummins brand diesel engine. In this developed model, MATLAB software is used to calculate engine performances and computer simulation based on engine volume reduction technology. Simulation results in the range of $1200 \mathrm{rpm}$ and $1800 \mathrm{rpm}$ engine speeds for the temperature and pressure values, flow rate and heat transfer rate in the cylinder and manifolds depending on the crank angle. As a result, it has been argued that the parameters such as injection angle, intercooler efficiency, turbocharger characteristics, intake and exhaust manifold volumes can be observed during the diagnostic process [4].

Muqeem referred about the requirements for use of turbochargers and intercooler in diesel and gasoline engines in his research. Then, he mentioned the general problems that can be seen in this binary system, which may occur due to seasonal conditions, engine speed status, etc. Moreover, it is emphasized that its ability to fill the cylinder with air is an indicator of the superiority of volumetric efficiency. In this study, in order to increase the turbocharging efficiency especially for the summer months, an intercooler system is developed both with the air conditioning system in the summer period and without needing for this in the winter period. Experimental performance tests were carried out on a four-stroke, four-cylinder turbocharged powered diesel engine. During engine operation at different speeds, the intercooler inlet and outlet air temperatures are measured with thermistors and recorded with an electronic measuring device. As a result, the air feed by a naturally aspirated engine with intercooling increased 1.43 times normal, and when cooled intercooler used 2,618 times increase was observed [5].

Tassou and Qureshi at Brunel University, they examined the performance variations of open type piston, semi-hermetic piston and open type rotary vane cooling compressors for variable speed capacity control applications. All three compressors are tested under constant and variable cylinder head pressures from 11 to 18 bar. Although screw and scroll compressors are adequate for variable speed applications, these two compressors are not preferred for tests due to their cooling capacities and commercial reasons. Volumetric effi- ciency is normally expected to increase as the speed decreases due to reduced throttling losses on the intake valves. However, it is seen that all three compressors are designed on the highest volumetric efficiency at design speed. As a result of the study, it was concluded from the tested compressors that the open type piston compressor configuration is the most suitable for variable speed operation. The analysis shows that the open-type piston compressor is the most efficient system that saves $12 \%$ when working in a mild climate and $24 \%$ when operating in a hot climate [6].

\section{Material and Method}

The experimental study test method performed is shown in Figure 1.

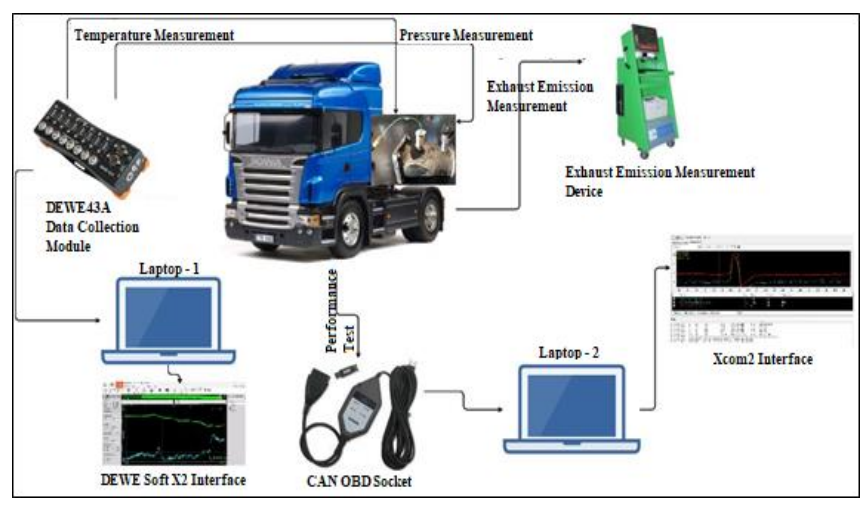

Fig. 1. Schematic view of the experimental test setup

Before starting the tests, the engine is operated at idling speed $(600 \mathrm{rpm})$ until the engine reaches nominally stable conditions (engine coolant reached ideal operating temperature) [7]. After the engine is reached its operating temperature, it is stopped and the drive wheels are lifted up in order to keep the vehicle at a constant speed. Just before each measurement, the tanks are drained to 0 bar by pulling the water drain valve pin underneath. In order to keep the vehicle at a constant speed with the cruise control system, performance tests are fixed at 750, 1250 and $1750 \mathrm{rpm}$ in 5th gear. The vehicle tank discharge pressure is checked to be 12 bar and when the tanks reaches the set pressure, the compressor is discharged.

\subsection{Test vehicle and compressor}

The experiments were done in Konanka Scania private service with the 2008 model Scania brand heavy vehicle. The technical properties of the vehicle used in the experimental studies are given in Table 1. The original equipment manufacturing of Knorr-Bremse brand is worked on the vehicle with a twin cylinder compressor. The technical specifications of the compressor are given in Table 2. 
Table 1. Technical specifications of Scania G 420

\begin{tabular}{c|c} 
Type & G 420 La x 2HNA \\
\hline Chassis serial no & 5218271 \\
\hline Vehicle/engine type & P, G, R, T serial truck (2003-) \\
\hline VIN & XLEG4X20005218271 \\
\hline Vehicle class & Tractor with semi-trailer \\
\hline Fuel type & Diesel \\
\hline Emission level & Euro 4 \\
\hline Injection system & HPI \\
\hline Number of cylinders & 6 \\
\hline Engine volume & 12 liter \\
\hline Engine power & $420 \mathrm{HP}$
\end{tabular}

Table 2. Technical specifications of Knorr-Bremse compressor $\operatorname{cod} 1796663$ [8]

\begin{tabular}{c|c} 
Product OEM number & $1796663 /$ K016615ES \\
\hline Cylinder bore & $88.00 \mathrm{~mm}$ \\
\hline Stroke & $50 \mathrm{~mm}$ \\
\hline Swept volume & $608 \mathrm{~cm} 3$ \\
\hline Air inlet port(s) size & M26x1,5 \\
\hline Air delivery port(s) size & M22x1,5 \\
\hline Number of cylinders & 2 \\
\hline Unloader port(s) size & M22x1,5 \\
\hline Cooling & Water \\
\hline Water port(s) size & M18x1,5 \\
\hline Lubrication & with Engine oil \\
\hline Oil supply Port size & Flange \\
\hline with ESS feature & Yes \\
\hline Water cooled valve plate & Yes \\
\hline Drive & Gear
\end{tabular}

\subsection{The methods used in data acquisition}

For both air inlet connection conditions, the motor indicated torque values and fuel consumption were measured from the CAN module with the Xcom2 software in the service and the data were recorded instantly. In both cases and at each determined speed, between 9 and 17 measurements were recorded and the arithmetic averages of the recorded values were taken. The amount of fuel consumed until the tank is full was obtained in liters by multiplying the tank filling time in hours for each case with the average data of $1 / \mathrm{h}$ taken from the CAN module.

During the measurement of the pressure and temperature values of the compressor inlet air through the interconnection, the Dewe 43A module of Dewesoft firm, which is widely used worldwide, was used. The technical specifications of the module are given in Table 3.

Table 3. Dewe43A technical specifications [11]]

\begin{tabular}{|c|c|}
\hline Number of channels & 8 \\
\hline Sampling rate & $200 \mathrm{kS} / \mathrm{s}$ \\
\hline Voltage ranges & $\begin{array}{c} \pm 10 \mathrm{~V}, \pm 1 \mathrm{~V}, \pm 100 \mathrm{mV}, \pm 10 \\
\mathrm{mV}\end{array}$ \\
\hline Sensor supply & $12 \mathrm{~V}, 400 \mathrm{~mA}$ \\
\hline Accuracy & $\pm 0,05 \% \mathrm{FS}$ \\
\hline Power supply & 6-36 VDC \\
\hline Number of counter input & 8 \\
\hline Power & $11 \mathrm{~W}$ \\
\hline Weight & $720 \mathrm{~g}$ \\
\hline
\end{tabular}

In order to measure the compressor inlet air pressure, the pressure sensor shown in Table 4, which has the technical characteristics of the Piezoresistive measurement capability with Trafag brand 16 bar absolute air pressure measurement capacity, was used. Pressure measurement was carried out through the analog input channel of the Dewe43A module.

Table 4. Technical specifications of pressure sensor [10]

\begin{tabular}{c|c} 
Peressure measuring range & $0-16$ bar \\
\hline Connection & $\mathrm{G} 1 / 4$ \\
\hline Accuracy & $\pm 0,5 \% \mathrm{FS}$ \\
\hline Working temperature $\left({ }^{\circ} \mathrm{C}\right)$ & $-40{ }^{\circ} \mathrm{C} \ldots+125^{\circ} \mathrm{C}$ \\
\hline Output signal $(\mathrm{V})$ & $0-10 \mathrm{VDC}$ \\
\hline Sensor supply $(\mathrm{V})$ & $9-32 \mathrm{VDC}$
\end{tabular}

The compressor air inlet temperature was recorded in a controlled manner instantly. Elimko brand $\mathrm{K}$ type temperature sensor was used for temperature measurement in the experiments. The technical specifications of the sensor are given in Table 5. Temperature measurement was done through the analog input channel of Dewe43A module using digital serial interface adapter (DSI).

While performing the tests, the data acquisition rate of the Dewesoft module can be determined. In the study, 21 data were collected per second. During the test, the measurements taken were observed and recorded with the software of DEWESoft X2. Both temperature and pressure data were recorded in an Excel file as mean value (Ave) and Rms (Root Mean Square). 
accepted for the filling mass, which can be taken under normal conditions in one cycle of the cylinder chamber volume. The temperature and pressure values of the inlet air were measured from the data acquisition module via sensors.

\subsection{Emission test}

The exhaust emission test was done in the place where

The experiments were first carried out in 3 different cycles, compressor air inlet supply in a conventionallynaturally aspirated after the air filter. Afterwards, as shown in Figure 2, the manifold pipe, with the sensor positioned on it and used as an interconnection, was placed between the intercooler and the engine block in order to perform turbocharged air feed compressor tests and experiments were carried out.

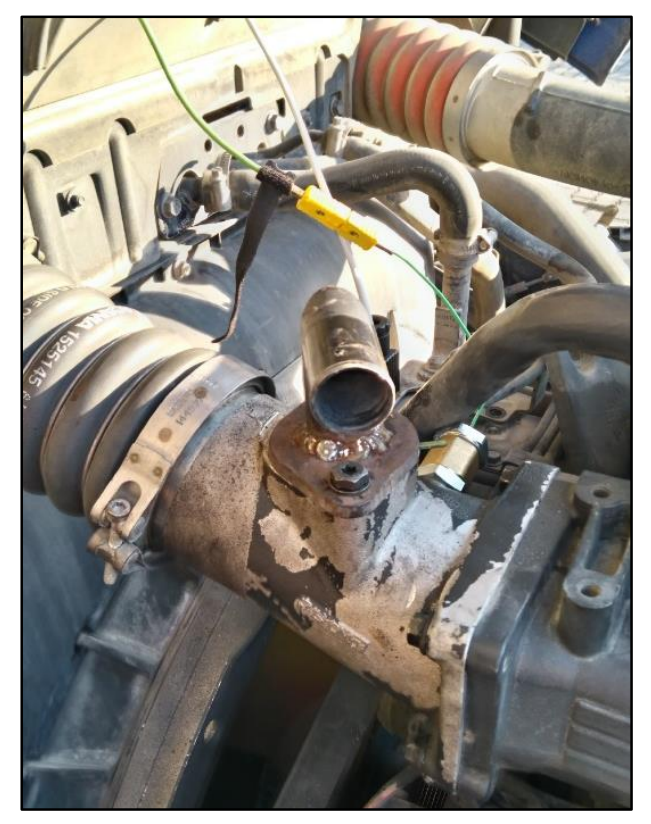

Fig. 2. Installation of the developed interconnection

\subsection{Calculation of volumetric efficiency}

Volumetric efficiency is indicated by $\eta_{\mathrm{v}}$. It is the ratio between the volume of free air delivered $\left(\mathrm{L}_{\mathrm{re}}\right)$ to the compressor per unit time and volume swept $\left(\mathrm{L}_{0}\right)$ by the piston per unit time. Volumetric efficiency is a value that directly affects compressor efficiency. The volumetric efficiency is calculated as in Equation 1 and the mass of the gas is calculated as a percentage with the ideal gas equation given in Equation 2 [12].

$$
\begin{aligned}
& \eta_{v}=L_{r e} / L_{0} \\
& P V=m R T
\end{aligned}
$$

where $\mathrm{P}$ represents pressure $(\mathrm{Pa}), \mathrm{V}$ volume $(\mathrm{m} 3), \mathrm{m}$ mass $(\mathrm{kg}), \mathrm{R}$ gas constant $(\mathrm{kj} / \mathrm{kgK})$ and $\mathrm{T}$ temperature $(\mathrm{K})$.

The temperature of $25^{\circ} \mathrm{C}$, pressure $1 \mathrm{~atm}(1,013 \mathrm{bar})$ was near the vehicle performance test service, without removing the interconnection mounted to the vehicle. For the first time, emission measurement was made for the turbocharged compressor feed. Since the vehicle was driven for a certain time, the engine was stopped and the tanks were emptied again. The emission class of the vehicle is selected as EURO IV from the measuring device software, so the limit values of the standard are determined. The measurement was made with the Federal brand exhaust gas analysis device, the technical specifications of the device are given in Table 6. After the measurement was completed, the screen data recorded, the vehicle stopped and the interconnection was removed. The emission test was also performed this time for the atmospheric feeding condition.

Table 6. Emission test device technical specifications

\begin{tabular}{c|c} 
Device & $\begin{array}{c}\text { Measuring of opacity exhaust } \\
\text { gas (Opacimeter) }\end{array}$ \\
\hline Brand & $\begin{array}{c}\text { Tecnoboss automotive } \\
\text { service equipment }\end{array}$ \\
\hline Model & 7000 \\
\hline Power supply & $0-40$ \\
\hline Ambient temperature & 203 \\
\hline $\begin{array}{c}\text { Epffective length (mm) } \\
\text { Opacity resolution and scale } \\
(\%)\end{array}$ & 0,1 \\
\hline $\begin{array}{c}\text { Light absorption resolution } \\
\text { and scale }\left(\mathrm{m}^{-1}\right)\end{array}$ & 0,01
\end{tabular}

\section{Results and Discussion}

The arithmetic means of the values measured in both RMS and AVE with the temperature and pressure sensors from the Dewesoft module was taken from Excel. The two-digit precision after the decimal part was considered and the two values are the same. The temperature and pressure values for the three cycles in which the experiments were carried out are shown in Figure 4 and Figure 5, respectively.

The purpose of a turbocharger is to increase the volumetric efficiency by increasing the density of the suction gas (usually air) by entering the suction line of the engine or compressor. When the inlet air pressure of the engine increases, its temperature also increases. The turbocharger technology uses an intercooler to cool the intake air. The aim is to bring the temperature of the air sucked as close to the ambient temperature as possible [5]. 


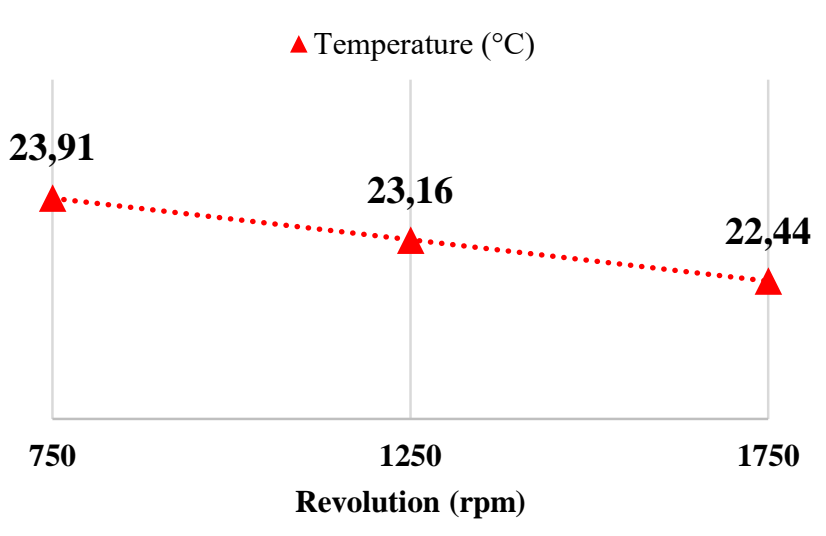

Fig. 3. Temperature values of measured in the interconnection

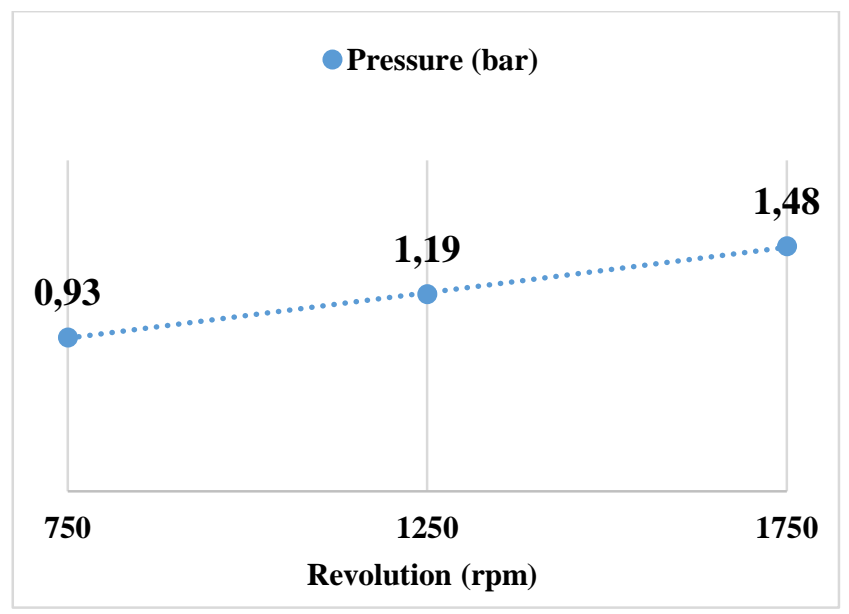

Fig. 4. Pressure values of measured in the interconnection

The temperature data shown in Figure 3, measured for three cycles during the turbocharged experiment, were observed quite close to the ambient temperature. The dimensions of the heavy vehicle intercooler core are both large and that the air passes through a longer hose up to the intake manifold compared to the passenger vehicles, and also being metal of the developed interconnection is increased the amount of heat transfer. The $0.70{ }^{\circ} \mathrm{C}$ differences in each cycle in temperature measurements were caused by the changing temperature and environmental factors during the tests.

Naser et al. in 2016 showed that in the study they conducted on a turbocharged Cummins diesel engine with cooling, turbocharger turbine speed increased almost parallel to engine speed from 1200 to $1800 \mathrm{rpm}$ [4]. The turbine shaft speed is approximately 30 times faster than the engine speed of a vehicle [13]. Thus, as the engine speed increases, it is observed that the measured pressure value increases after the air passes through the intercooler as shown in Figure 4.

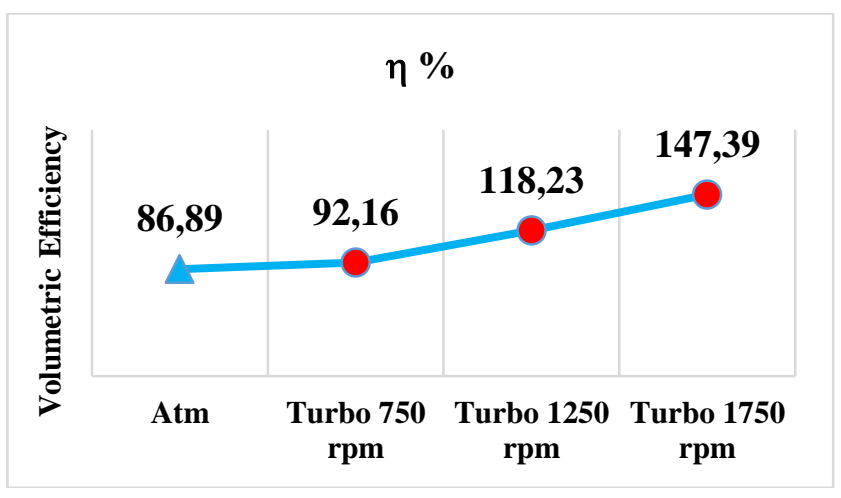

Fig. 5. Volumetric efficiency

As pointed out in the study of Muuqem in 2012, volumetric efficiency increases as the density of the air taken into the cylinder increases by the turbocharger [5]. As can be seen in Figure 5 in the study, it was observed that volumetric efficiency increases with turbocharged feeding. At the same time, Naser et al. showed in the 2016 study that as the engine speed increases, the turbocharger shaft speed increases. For this reason, a linear increase in volumetric efficiency was observed in this study as the engine speed increased [4]. As a result of these, a decrease in the air tank filling time given in "minutes:seconds" was observed in Figure 6 due to the increase in the speed and the flow rate of the air pumped in the compressor fed by turbocharged compared to the naturally aspirated compressor.

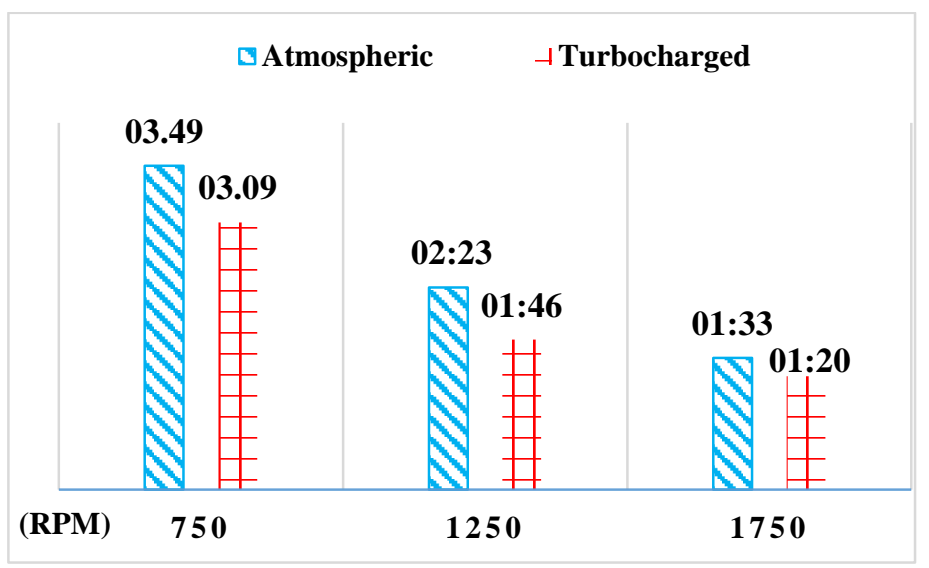

Fig. 6. Air tank filling times

When the compressor inlet air is fed by turbocharged, the tank filling times have decreased due to the increase in volumetric efficiency. In the case of turbocharged compressor air inlet, this reduction is found to be $17 \%$ in the measurements performed at $750 \mathrm{rpm}, 25 \%$ at $1250 \mathrm{rpm}$ and $14 \%$ at 1750 rpm. Tassou and Qureshi in their study 1998 stated that would result in throttling losses across the suction valves at high speeds [6]. The decrease of time as the tanks were filling was less observed due to the decrease in compressor valve 
efficiency at high speeds.

The indicated torque values and their averages obtained from the engine CAN module for both compressor air inlet connections are given in Figure 10, Figure 11 and Figure 12, respectively, for 750, 1250 and $1750 \mathrm{rpm}$. Ünüvar et al. showed that in 2019, in an experimental study on heavy vehicle air brake compressor performance showed that the amount of air flow increased with the increasing speed and thus the amount of power driven by the compressor crankshaft [14]. In this experimental study, the compressor air flow increases when the cycle increases. At the same time, when the compressor air inlet is fed with turbocharged air, the volumetric efficiency increases as the density of the inlet air will increase. Therefore, the rate of torque required by the compressor gear has increased. As can be seen from the graphs, the indicated torque values measured from the engine have increased as the speed increased and the connection of turbocharged compressor compared to the atmospheric intake air inlet.

The instantaneous fuel consumption values measured from the vehicle CAN module are given in Figure 13, Figure 14 and Figure 15 according to the cycle at which the experiment is carried out. The amount of fuel consumed until the tanks are filled for each experiment is shown in Figure 7 in liters. It is calculated by multiplying instant fuel consumption average values by tank filling times.

Instant fuel consumption increased both with the compressor inlet air fed from the turbocharger and as the engine speed increased. However, the decrease in tank filling times shows decrease as seen in Figure 7 in the amount of fuel consumption in the entire system until the tanks are full.

The increase in the amount of torque also causes an increase in the amount of fuel consumption. Combustion in diesel engines involves the complex physical and chemical events that occur during the period from the start of the injection of fuel to the combustion chamber until the beginning of the exhaust time when the products of combustion are emitted. There is no homogeneous mixture in the combustion chamber in compression-ignition engines [15]. This is the main reason for the minor differences in the instant data as a result of the measurements in the graphs.

The emission value display image measured of naturally aspirated compressor air inlet is given in Figure 8, and the turbocharged compressor air inlet line emission value is given in Figure 9.

The area shown as "Ölçüm 0" on the screen shows the value before the measurement starts when the measuring probe is attached to the exhaust. The "Sicaklık" section on the display indicates the value of ambient temperature. The "Opasite", which is shown in red just to the left of it, indicates the instant opacity. As seen from the graphics at the top of the screens, after the emission tests, the device encountered a certain smoke density in the atmospheric connection. This is the reason for the difference between the two measurement screens. The final result of the measurements is the section indicated by "Sonuç" on the screen, and the values used in its calculation are expressed in "Ölçüm 1", "Ölçüm 2" and "Ölçüm 3". With the values taken from these three consecutive measurements, the result value calculated with the Bessel algorithm specified in ISO 8178-9 (Reciprocating internal combustion engines - Exhaust emission measurement Part 9) in certain percentages was obtained. "Ölçüm 0 " value is excluded in the calculation because it gives a value for the situation before the measurement is performed.

\section{Fuel Consumption (L.)}

$750 \mathrm{rpm}$ Atmospheric $750 \mathrm{rpm}$ Turbocharged

$\equiv 1250 \mathrm{rpm}$ Atmospheric $\equiv 1250 \mathrm{rpm}$ Turbocharged

III $1750 \mathrm{rpm}$ Atmospheric IIII $1750 \mathrm{rpm}$ Turbocharged

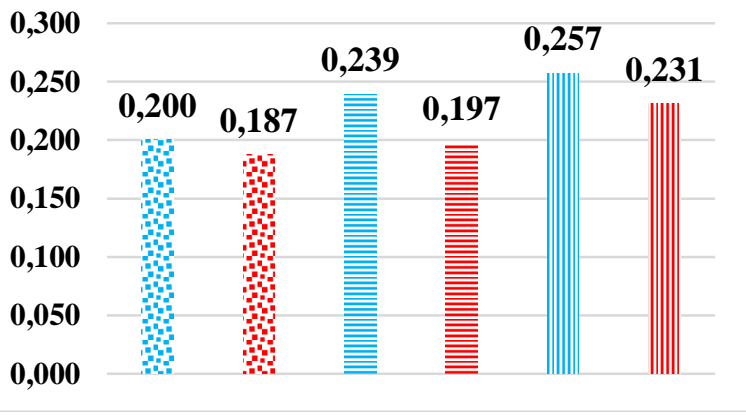

Fig. 7. Amount of fuel consumption in the vehicle until the tanks are full

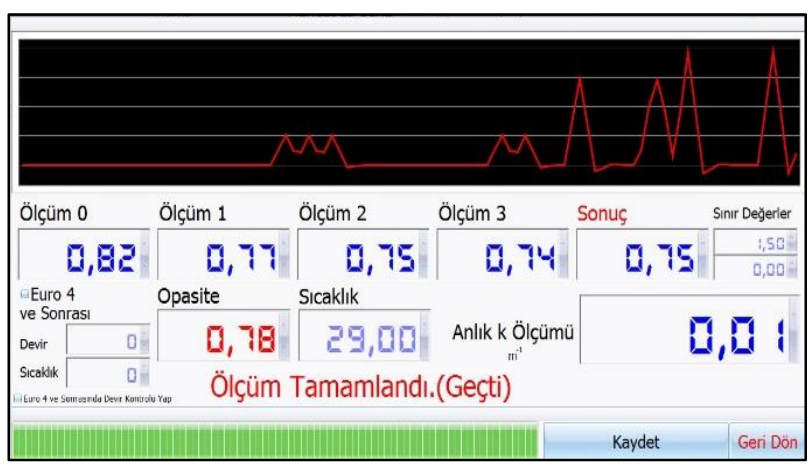

Fig. 8. Atmospheric compressor feed emission result

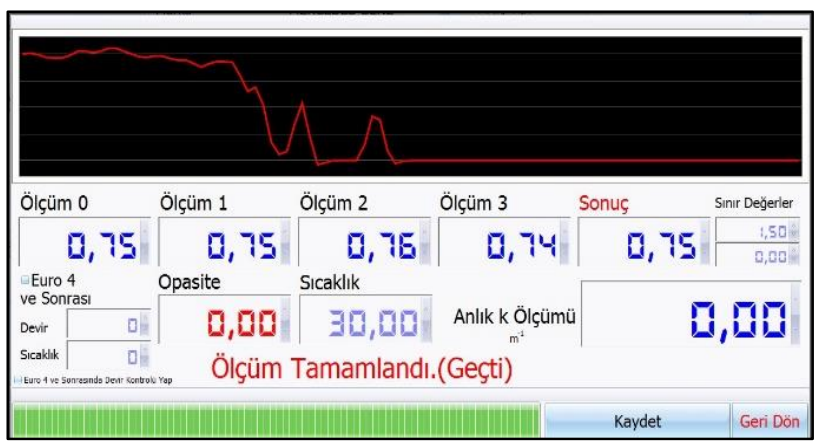

Fig. 9. Turbocharged compressor feed emission result 


\section{RPM}

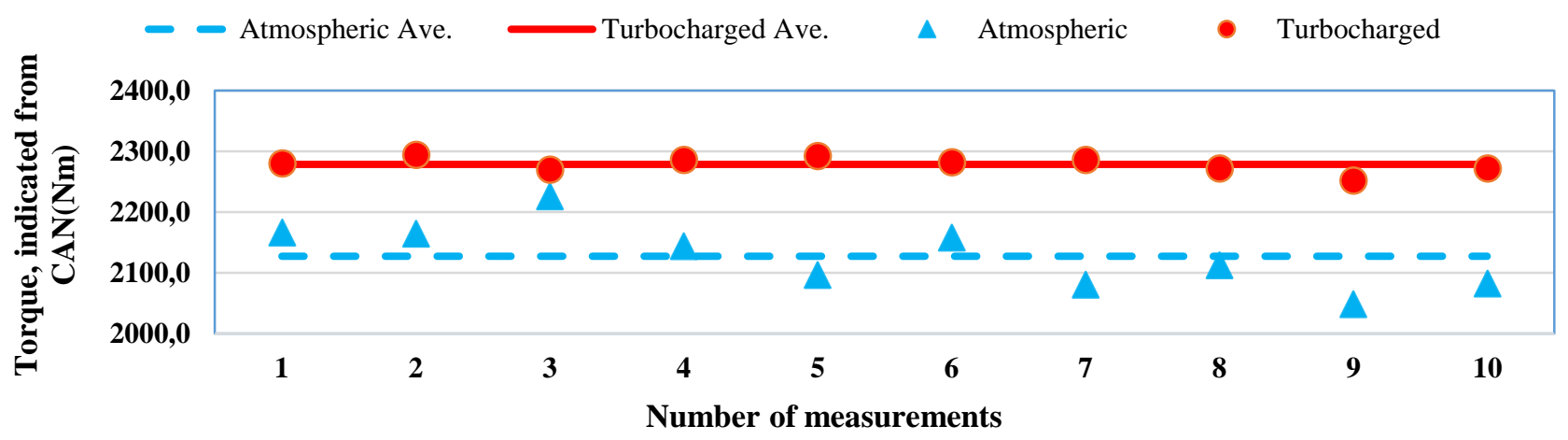

Fig. 10. $750 \mathrm{rpm}$ engine indicated torque values

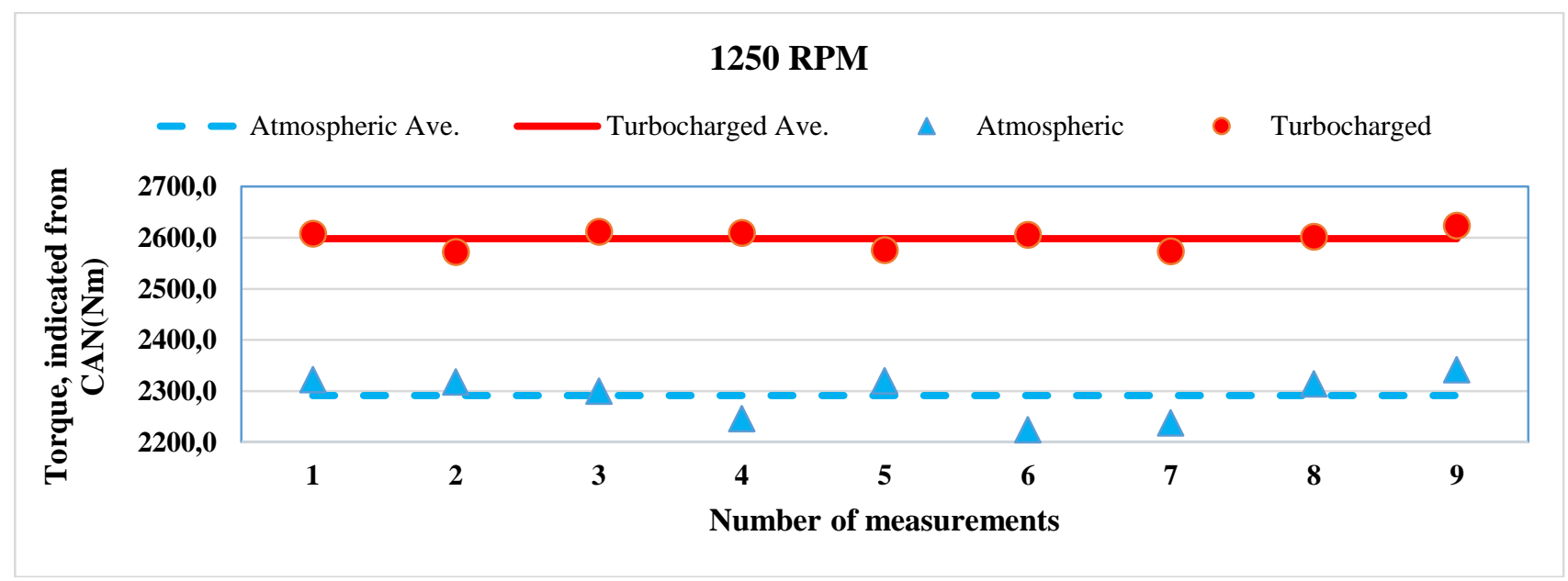

Fig. 11. $1250 \mathrm{rpm}$ engine indicated torque values

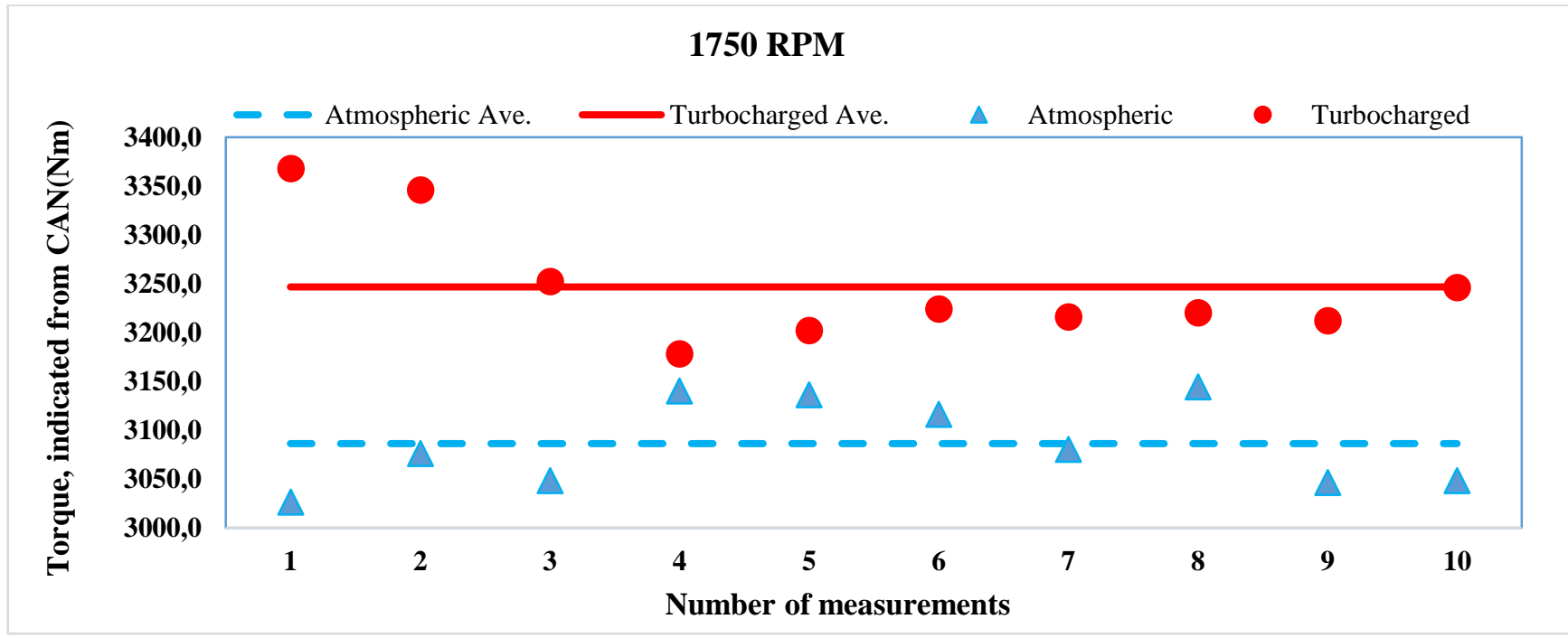

Fig. 12. $1750 \mathrm{rpm}$ engine indicated torque values 


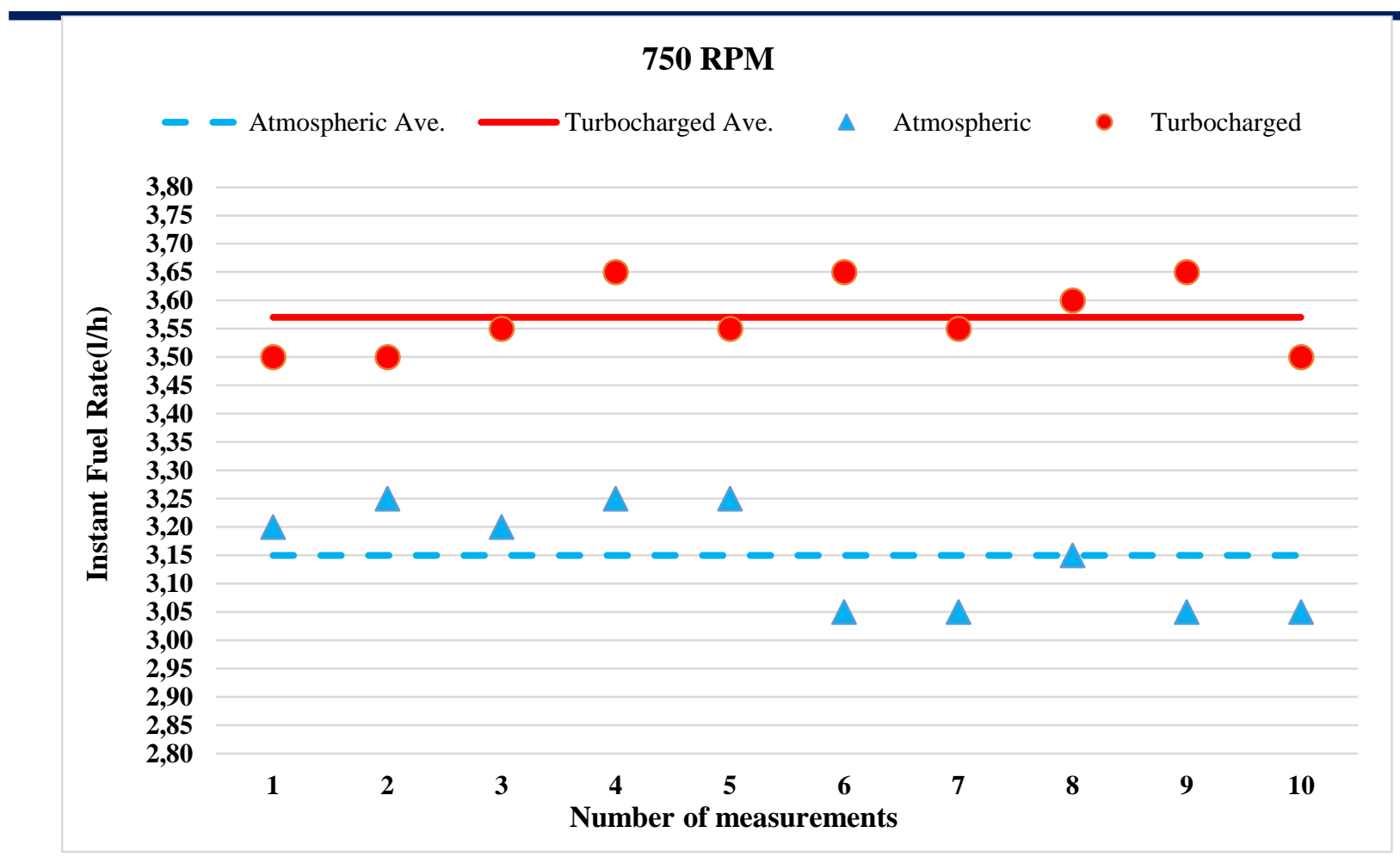

Fig. 13. $750 \mathrm{rpm}$ instant fuel consumption values

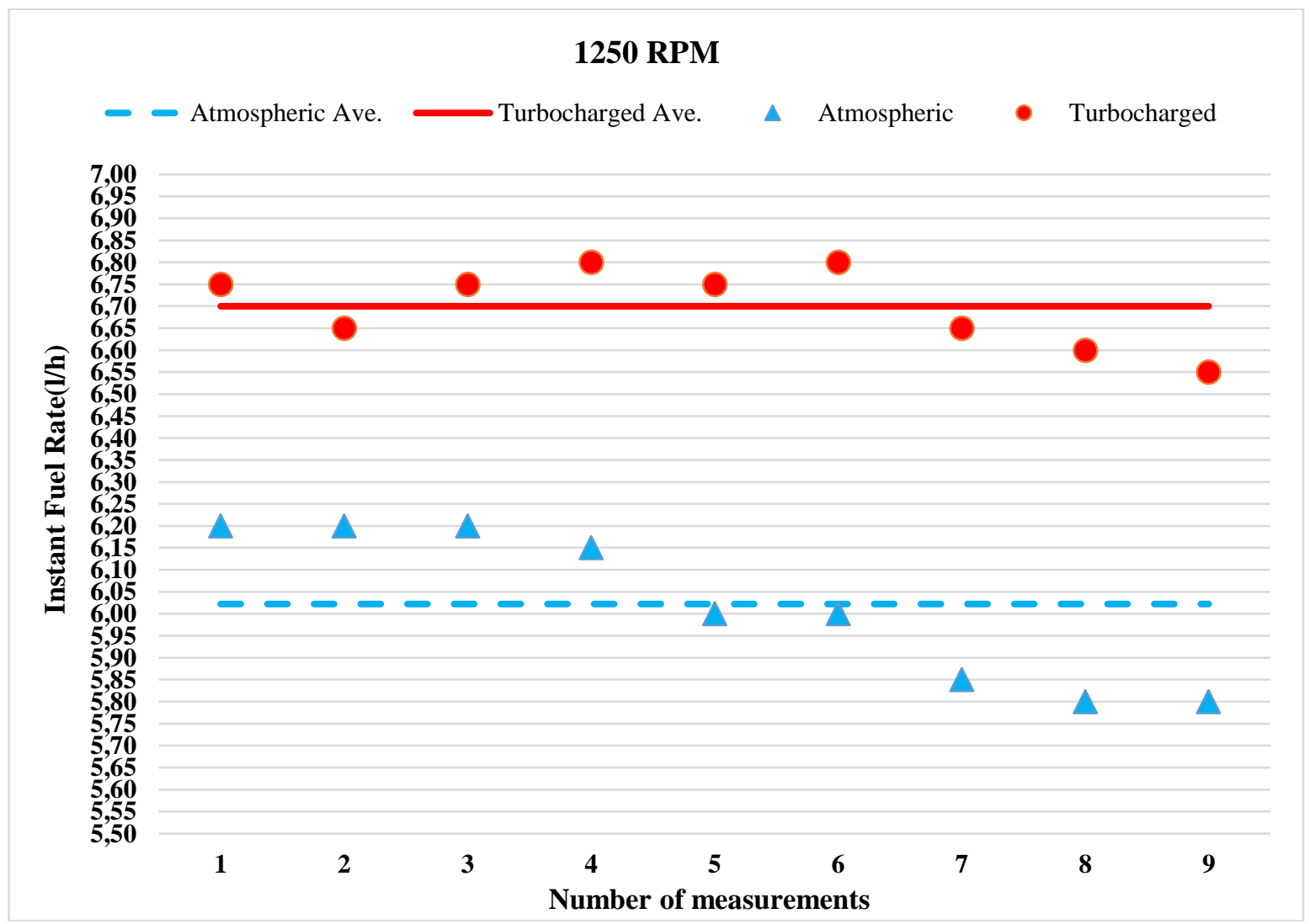

Fig. 14. $1250 \mathrm{rpm}$ instant fuel consumption values 


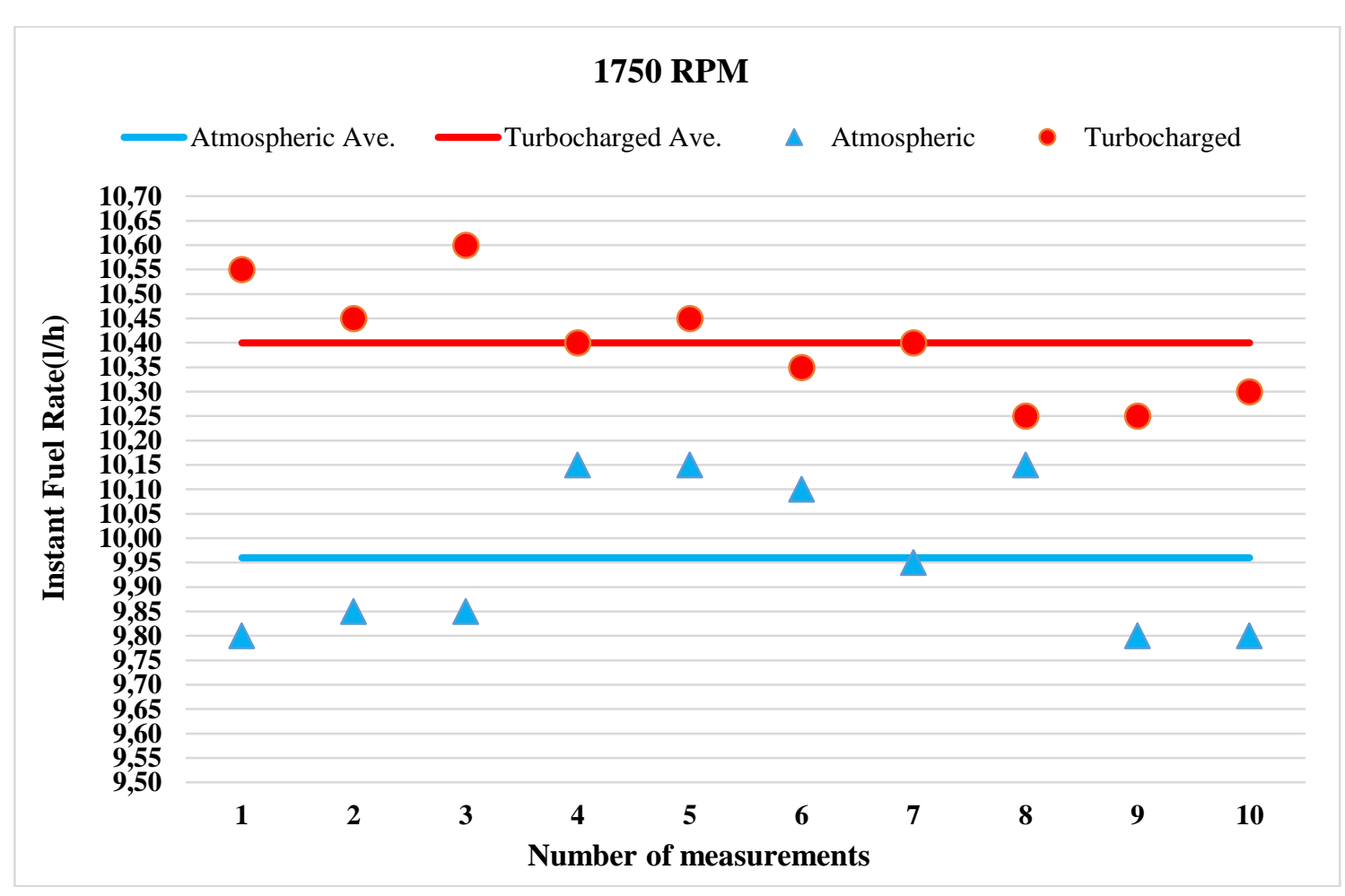

Fig. 15. $1750 \mathrm{rpm}$ instant fuel consumption values

In the regulation "Egzoz Gazı Emisyonu Kontrolü İle Benzin Ve Motorin Kalitesi Yönetmeliği - Ek2", the absorption coefficient limit values for diesel vehicles in traffic are shown in Table 7.

In this regulation, the exhaust gas emission measurement principles and limit values are explained in "Madde - 8", in order to provide maximum feeding from the injection pump, to depress the gas pedal fully and continuously but not hard. Exhaust gas flow accelerates due to the engine speed increases at full throttle during the measurement. As the turbocharger turbine driven by the kinetic energy of the exhaust gases goes up to high speeds, it has been able to reach the air flow to feed both the 12-liter internal combustion engine and the 0.6-liter compressor. Therefore, the results were measured the same in both cases.

Table 7. Absorption coefficient limit values for diesel vehicles in traffic [16]

\begin{tabular}{c|c}
$\begin{array}{c}\text { INFORMATION ABOUT THE } \\
\text { VEHICLE }\end{array}$ & $\begin{array}{c}\text { ABSORPTION } \\
\text { COEFFICIENT } \\
\left(\mathrm{m}^{-1}\right)\end{array}$ \\
\hline - Naturally aspirated diesel engines & 2,5 \\
\hline - Diesel engines with turbocharger & 3,0 \\
\hline - Diesel engines manufactured after 2010 & 1,5
\end{tabular}

\section{Conclusion}

In this study, experimental studies were carried out when a naturally aspirated reciprocating air compressor and the same compressor were supplied with air from the turbocharger intercooler via an interconnection. The results are listed as follows in terms of compressor, engine and emission:

- When assesed in terms of compressor performance, while the volumetric efficiency of the atmospheric feed compressor was $86.89 \%$, it increased as the engine speeds of 750,1250 and $1750 \mathrm{rpm}$ by $6 \%, 36 \%$ and $69 \%$, respectively, in the turbocharged state. Thus, in terms of tank filling times, shortening has been achieved for the connection type of turbocharged feeding.

- An increase was observed in the indicated torque and instant fuel consumption values taken from the engine CAN module with the turbocharged compressor compared to the naturally aspirated compressor. In terms of fuel consumption in the vehicle until the tanks are full; because the turbocharged pressured air is pumped in shorter time, the total consumption of the fuel was decreased even the instant fuel consumption increased.

- For the emission measurement results with opacimeter, the absorption coefficient for both cases was measured $0.75 \mathrm{~m}^{-1}$ and this value is within the allowable values of a vehicle with EURO IV standard.

With this study, it has been shown that the compressor 
air inlet line can be fed through a connection from the turbocharger intercooler in heavy vehicle types such as construction site vehicles, garbage trucks, and urban transportation especially municipality buses where pressurized air is highly needed. In this case, the duty cycle, which the compressor original equipment manufacturers have mentioned in the troubleshooting guides, is shortened, and additional maintenance costs and time are reduced.

\section{Acknowledgment}

This study was supported by Selçuk University Scientific Research Foundation in frame of the project no of 19201128. As researchers, we thank Scientific Research Foundation of Selçuk University. We also thank Yıldız Pul Otomotiv Motor Marçaları Sanayi A.Ş.

This study is derived from Gökselhan Kula's master's thesis entitled "Integrated Investigation of Air Brake Compressor and Air Line in New Technology in Heavy Duty Type Vehicles".

\section{Abbreviations}

$\begin{array}{ll}C A N & : \text { controller area network } \\ F S & \text { : full-scale } \\ H P & : \text { horse power } \\ H P I & \text { : high pressure injection } \\ \text { ISO } & \begin{array}{l}\text { : International Organization for Stand- } \\ \text { ardization }\end{array} \\ r p m & \text { : revolution per minute } \\ V I N & \text { : vehicle identification number }\end{array}$

\section{References}

[1] Kula, G., Ciniviz, M. ve Toy, İ. (2019). Investigation of running as a result of heavy duty vehicle compressors with conditioned air feed, ISPEC 5th International Conference on Engineering \& Natural Sciences, Van, 580-593.

[2] LLC., B. C. V. S., (2004). Introduction to the air brake charging system, advance troubleshooting guide for air brake compressors 2 .

[3] Shinde, A. ve Jadhav, H. (2017). Energy saving through air compressor system automation, 2017 International Conference on Circuit, Power and Computing Technologies (ICCPCT), 1-7.

[4] Naser, L., Ilir, D. ve Shpetim, L. (2016). Modelling and simulation of the turbocharged diesel engine with intercooler, IFAC-PapersOnLine, 49 (29), 237-242.

[5] Muqeem, M. (2012). Turbocharging with air conditioner assisted intercooler, Journal of Mechanical and Civil Engineering, 2 (3), 38-44.
[6] Tassou, S. ve Qureshi, T. (1998). Comparative performance evaluation of positive displacement compressors in variable-speed refrigeration applications, International Journal of Refrigeration, 21 (1), 29-41.

[7] Chiavola, O., Palmieri, F. ve Recco, E. (2018). Vibration analysis to estimate turbocharger speed fluctuation in diesel engines, Energy Procedia, 148, 876-883.

[8] Anonim, KNORR-BREMSE Türkiye, https://www.knorrbremse.com.tr/tr/commercialvehicles/products $1 /$ productsearch_1/search.jsp: [March, 18].

[9] Anonim, Termokupullar ile İlgili Genel Bilgiler, https://www.elimko.com.tr/files/TermokupllarGenelBilgiler.pdf:

[10]Anonim, Industrial Pressure Transmitter, https://www.alfasanayi.com/content/img/EPI/H72317i_EN_8287_EPI_Industrial_Pressure _Transmitter.pdf: [March, 18].

[11]Pişirici, S., (2017). Üç kademeli tek etkili pistonlu kompresörün dinamik analizi, Yüksek Lisans Tezi, Yıldız Teknik Üniversitesi, 104

[12]Çengel, Y. ve Boles, M., (1996). Mühendislik Yaklasimiyla Termodinamik, Çev. T. Derbentli). Istanbul: Literatür Yayincilik.

[13]Ingale, M., Kawale, H., Thakre, A. ve Shrikhande, N., (2010). Performance enhancement of engine using turbocharger: A Review.

[14]Ünüvar E., Gül E., Aydıner M. Ş. ve Kalyoncu M., (2019). Investigation of the effect of intake and exhaust valve dimensions on performance for heavy duty vehicle air compressors, The International Aluminium-Themed Engineering and Natural Sciences Conference (IATENS'19), Seydişehir/TURKEY, 556-559.

[15]Safgönül, B., Ergeneman, M., Arslan, H. E. ve Soruşbay, C. (2013). İçten yanmalı motorlar, Birsen Yayınevi, p.

[16]Resmi Gazete, (2013). Egzoz Gazi Emisyonu Kontrolü İle Benzin ve Motorin Kalitesi Yönetmeliği p. 